\title{
UJI DAYA HAMBAT EKSTRAK ETANOL DAUN BANDOTAN (Ageratum conyzoides L.) SEBAGAI ANTIBAKTERI DALAM MENGHAMBAT PERTUMBUHAN Staphylococcus aureus PENYEBAB BISUL
}

\author{
*)Muh. Farid Hasyim \\ *)Akademi Farmasi Sandi Karsa Makassar \\ *)Program Studi D-III Farmasi Sandi Karsa Makassar
}

\begin{abstract}
ABSTRAK
Telah dilakukan penelitian dengan tujuan untuk mengetahui Uji Daya Hambat Ekstrak Etanol Daun Bandotan (Ageratum Conyzoides L.) Sebagai Antibakteri Dalam Menghambat Pertumbuhan Staphylococcus Aureus Penyebab Bisul. Jenis penelitian adalah eksperimental laboratorium dengan menggunakan ekstrak etanol dengan konsentrasi 15\%, 25\% dan 35\% ekstrak etanol daun bandotan, DMSO (Dimetyhl sulfoxide) sebagai kontrol negatif, dan sefadroxil sebagai kontrol positif. Dilakukan replikasi sebanyak 3 kali pada setiap kelompok perlakuan. Hasil penelitian menunjukkan adanya zona hambat setelah 1x24 jam, zona hambat yang menghasilkan daya hambat paling besar adalah pada konsentrasi $35 \%$ sebesar $26,94 \mathrm{~mm}$. Dari penelitian ini disimpulkan bahwa ekstrak etanol daun Bandotan (Ageratum conyzoides L.) mempunyai aktivitas antibakteri terhadap pertumbuhan Staphylococcus aureus.
\end{abstract}

Kata Kunci : Uji Daya Hambat, Daun Bandotan, Staphylococcus aureus.

\section{PENDAHULUAN}

\section{A. Latar Belakang}

Indonesia merupakan Negara tropis dengan jumlah tanaman yang sangat banyak. Keanekaragaman hayati Indonesia merupakan nomor 2 setelah Brazil. Sekitar 80\% tanaman yang ada didunia berada di Indonesia. Diperkirakan terdapat 25.000-30.000 spesies tanaman di Indonesia. Penggunaan obat tradisional oleh nenek moyang bangsa Indonesia telah berlangsung lama (Sutrisna, 2016).

Tumbuhan bandotan sejak dahulu telah digunakan secara luas dalam pengobatan tradisional oleh masyarakat, antara lain untuk pengob atan luka, gangguan pencernaan dan diare (Sugara, 2016).

Daun bandotan mempunyai efek spasmolitik dan analgesik serta memberikan pengaruh relaksasi pada otot polos. Daun bandotan dapat memberikan pengaruh menenangkan (Andriani, 2018).

Tanaman bandotan banyak juga digunakan untuk mengobati penyakit kulit seperti bisul, bengkak, dan borok. Penyakit kulit dapat disebabkan oleh bakteri Staphylococcus aureus, dan Staphylococcus sp (Utami, 2012).

Pengobatan penyakit kulit yang disebabkan oleh bakteri Staphylococcus aureus dengan menggunakan antibiotik secara topikal atau oral. Selain menggunakan obat antibiotik, masyarakat biasanya lebih sering menggunakan tanaman berkhasiat sebagai obat, contoh tanaman yang digunakan sebagai obat penyakit kulit adalah bandotan. Bandotan memiliki bahan kandungan diantaranya meliputi glikosida, tannin, alkaloid, resin, sapponin, flavonoid, terpen, polifenol, dan minyak atsiri. Sedangkan, bagian akarnya mengandung fenolik dan terpenoid (Utami, 2012).

Bakteri Staphylococcus aureus adalah bakteri yang pertama kali ditemukan oleh Sir Alexander ogston padaabad ke-19, dia adalah seorang ahli beda Skotlandia dan ahli mikrobiologi amatir. Staphylococcus aureus secara normal merupakan penduduk kulit dan rongga hidung yang tidak berbahaya. Namun, ia memiliki potensi yang kuat untuk menyebabkan spectrum luas sindrom klinis mualai dari infeksi kulit ringan hingga septikimia yang berlebihan (Fetsch Alexander, 2017).

Dari penelitian sebelumnya oleh Harun (2017) menggunakan 4 konsentrasi yang meliputi konsentrasi 20\%, 40\%, 60\%, dan $80 \%$. Menggumakan bakteri uji Staphylococcus aureus Hasil yang diperoleh semua konsentrasi ekstrak daun bandotan (Ageratum conyzoides L.) mempunyai aktivitas antibakteri. Untuk konsentrasi $80 \%$ respon hambatan sangat kuat dengan hasil $45 \mathrm{~mm}$. untuk konsentrasi $60 \%$ menghasilkan zona hambat yang sedikit dengan hasil $35,7 \mathrm{~mm}$.

Oleh karena itu penulis melakukan penelitian lebih lanjut, dengan memakai konsentrasi yang lebih rendah dari penelitian sebelumnya. Selain itu karena adanya pengalaman empiris dari masyarakat sekitar penulis semakin mendorong untuk melakukan penelitian agar di peroleh informasi yang ilmiah. 
Dengan adanya informasi tersebut dapat memberikan pemahaman tentang tanaman Bandotan khususnya bagian daun yang dapat digunakan sebagai alternatif pengobatan antibakteri yang mudah ditemukan dan aman.

\section{B. Rumusan Masalah}

Rumusan masalah pada penelitian ini adalah :

1. Apakah ekstrak etanol daun Bandotan (Ageratum conyzoides L.) memiliki aktivitas antibakteri terhadap Staphylococcus aureus?

2. Pada konsentrasi berapa ekstrak etanol daun Bandotan (Ageratum conyzoides L.) memberikan aktivitas antibakteri terhadap Staphylococcus aureus ?

\section{Tujuan Penelitian}

Penelitian ini bertujuan untuk :

1. Mengetahui aktivitas ekstrak etanol Daun Bandotan (Ageratum conyzoides L.) terhadap Staphylococcus aureus.

2. Mengetahui pada konsentrasi berapa ekstrak etanol daun Bandotan (Ageratum conyzoides L.) memberikan aktivitas antibakteri terhadap pertumbuhan Staphylococcus aureus.

\section{Manfaat Penelitian}

Manfaat dari penelitian ini yaitu untuk memberikan informasi ilmiah mengenai daya hambat ekstrak etanol daun bandotan (Ageratum Conyzoides L.) sebagai antibakteri dalam menghambat pertumbuhan Staphylococcus aureus penyebab bisul sehingga penggunannya dapat dipertanggung jawabkan secara ilmiah. Hasil penelitian diharapkan menjadi dasar penelitian Daun Bandotan (Ageratum conyzoides L.) sebagai obat alternatif untuk menangani penyakit infeksi yang disebabkan oleh bakteri tersebut.

\section{METODE PENELITIAN}

\section{A. Jenis Penelitian}

Jenis penelitian ini merupakan penelitian eksperimen laboratorium dengan melakukan penelitian untuk mengetahui uji daya hambat ekstrak etanol daun bandotan (Ageratum conyzoides L.) sebagai antibakteri dalam menghambat pertumbuhan Staphylococcus aureus.

\section{B. Waktu Dan Tempat Penelitian}

Penelitian ini akan dilaksanakan di Laboratorium Biologi Akademi Farmasi Sandi Karsa Makassar, yang dilaksanakan pada Bulan Maret 2020.

\section{Populasi dan Sampel}

Populasi dari penelitian ini adalah daun Bandotan (Ageratum conyzoides L.) yang di peroleh dari Perumahan Greenhilss, jalan poros pamenjengan, Moncongloe Kabupaten Maros Sulawesi Selatan.

Sampel yang digunakan adalah sampel daun Bandotan di ambil daun kelima dari pucuk dipetik satu per satu secara manual, daun yang di ambil daun yang berwarna hijau dan dalam kondisi tidak rusak dan waktu pengambilannya pada pagi hari dari jam $07.00-10.00$.

\section{Alat dan Bahan Penelitian}

a. Alat yang digunakan (Merek)

Autoklaf (Medical Oxygen Gauge), Batang pengaduk, Botol pengencer, Bunsen, Cawan petri(Normax), Erlenmeyer (Pyrex), Gelas ukur (Pyrex), Gelas kimia (Approx), Inkubator (Wina Instrumenty), LAF (Heles), Pinset, Rak tabung reaksi, Sendok tanduk, Spoit, Ose, Penangas air,Tabung reaksi (Pirex), Timbangan analitik (CHQ), Jangka sorong(Mitutoyo).

b. Bahan

Bahan yang digunakan antara lain: Aluminium foil, Aquadest, Biakan murni Staphylococcus aureus, Cefadroxil, DMSO (Dimetyhl sulfoxide), Kapas, Kertas label, Medium Nutrien Agar (NA), tissue, larutan Nacl 0,9\%, Plastik Wrap, Paper disk , Tanaman daun Bandotan (Ageratum conyzoides L.) sebagai sampel.

\section{E. Prosedur Penelitian}

1. Pengambilan Bahan Uji

Daun Bandotan (Ageratum conyzoides L.), di ambil daun kelima dari pucuk dipetik satu per satu secara manual dan waktu pengambilannya pada pagi hari dari jam $07.00-10.00$.

2. Proses Pengolahan Bahan Uji

Daun Bandotan yang diperoleh kemudian dilakukan metode ekstraksi maserasi untuk mendapatkan ekstrak dari daun Bandotan tersebut.

3. Sterilisasi Alat

Alat-alat yang digunakan dicuci dengan detergen, kemudian dibilas dengan air bersih. Alat-alat dikeringkan dengan posisi terbalik dan terbuka, setelah kering, disterilkan di Autoklaf pada suhu $121^{\circ} \mathrm{C}$ selama 15 menit tekanan 2 atm. Pinset dan ose disterilkan dengan cara pemanasan langsung dengan nyala api

4. Pembuatan Medium

a. Medium Nutrien Agar (NA)

Ditimbang Nutrient Agar 2,3 gram dan dimasukkan kedalam Erlenmeyer $100 \mathrm{ml}$ kemudian dilarutkan dengan $100 \mathrm{ml}$ air 
lalu dihomogenkan, Dipanaskan di hot plate sambil diaduk hingga larutan mendidih, kemudian ditutup dengan aluminium foil. Setelah itu disterilkan dalam autoklaf pada suhu $121{ }^{\circ} \mathrm{C}$ selama 15 menit.

5. Penyiapan Bakteri Uji

a. Peremajaan kultur murni bakteri

Bakteri uji berupa Staphylococcus aureus yang berasal dari biakan murni, diambil 1 ose pada bakteri secara aseptis, kemudian diinokulasi pada agar miring dengan cara digoreskan pada medium Nutrien Agar (NA) miring dan diinkubasi pada suhu $37^{\circ} \mathrm{C}$ selama 24 jam secara steril didalam Laminar Air Flow (LAF) sehingga diperoleh bakteri murni.

b. Pembuatan suspensi bakteri uji

Bakteri uji hasil peremajaan selanjutnya diambil 1 ose kemudian disuspensikan kedalam tabung reaksi yang berisi $10 \mathrm{ml}$ $\mathrm{NaCl} \quad 0,9 \% \quad$ steril, kemudian dihomogenkan.

6. Pembuatan ekstrak etanol daun Bandotan (Ageratum conyzoides L.)

Timbang simplisia yang telah menjadi serbuk sebanyak 500 gram dan masukan dalam wadah. Tuangkan pelarut etanol $70 \%$ sampai simplisia terendam kemudian tutup wadah dengan rapat. Diamkan selama 3$5 \times 24$ jam dengan sesekali diaduk. Kemudian saring sehingga diperoleh ekstrak daun Bandotan.

7. Pembuatan Bahan Uji

Pada pembuatan bahan uji dibuat dalam kosentrasi $15 \%, 25 \%$, dan $35 \%$ dengan cara di timbang ekstrak etanol daun Bandotan (Ageratum conyzoides L.).

8. Pembuatan larutan pembanding

Larutan kontrol positif menggunakan Sefadroxil dan kontrol negative menggunakan DMSO (Dimetyhl sulfoxide).

9. Pengujian Bahan Uji

Pengujian Pemberian ekstrak etanol daun Bandotan (Ageratum conyzoides L.) terhadap bakteri uji dilakukan dengan metode difusi agar dengan menggunakan paper disk. Medium NA steril dipanaskan sampai mencair kemudian didinginkan hingga suhu $45^{\circ} \mathrm{C}$ kemudian diambil $15 \mathrm{ml}$ medium tersebut kemudian ditambahkan suspensi bakteri uji sebanyak $1 \mathrm{ml}$, kocok sampai homogen, kemudian dituang ke dalam cawan petri dan dibiarkan setengah memadat. Kemudian masing-masing paper disk dicelupkan dalam suspensi ekstrak dengan konsentrasi 15\%, 25\%, 35\% untuk kontrol positif Sefadroxil. Setelah itu paper disk diletakkan secara aseptis dengan menggunakan pinset pada permukaan medium NA dalam cawan petri. Jarak antara paper disk disekitar $20 \mathrm{~mm}$ dari tepi cawan petri. Kemudian di inkubasi pada suhu $37^{\circ} \mathrm{C}$ selama 24 jam, pengamatan dilakukan setelah 1 x 24 jam.

10. Pengamatan

Setelah bakteri uji diinkubasi selama 1 x 24 jam kemudian diukur zona hambatan yang terjadi pada masing-masing konsentrasi ekstrak pada bakteri uji dalam satuan millimeter (mm). Setelah itu dilanjutkan inkubassi bakteri selama 24 jam untuk mengetahui sifat daya hambat dari sampel daun Bandotan (Ageratum conyzoides L.)

\section{HASIL DAN PEMBAHASAN}

\section{A. Hasil Penelitian}

Hasil pengujian uji aktivitas antibakteri ekstrak etanol daun Bandotan (Ageratum conyzoides L.) terhadap pertumbuhan Staphylococcus aureus dapat dilihat pada tabel berikut.

Tabel I. Hasil pengamatan uji daya hambat ekstrak etanol daun Bandotan (Ageratum conyzoides L.) terhadap pertumbuhan Staphylococcus aureus

\begin{tabular}{cccccc}
\hline \multirow{3}{*}{ Replikasi } & \multicolumn{5}{c}{ Diameter Zona Daya Hambat (mm) } \\
\cline { 2 - 6 } & \multicolumn{3}{c}{ Konsentrasi } & \multicolumn{3}{c}{ Kontrol } \\
\cline { 2 - 6 } & $\mathbf{1 5 \%}$ & $\mathbf{2 5 \%}$ & $\mathbf{3 5 \%}$ & Kontrol (-) & Kontrol (+) \\
\hline I & 22.93 & 24,8 & 27,3 & 0 & 34,53 \\
\hline II & 23,26 & 25,53 & 26,96 & 0 & 33,23 \\
\hline III & 21,9 & 25,06 & 26,53 & 0 & 32,26 \\
\hline Jumlah & 68,09 & 75,39 & 80,83 & 0 & 100,03 \\
\hline Rata-Rata & 22,70 & 25,13 & 26,94 & 0 & 33,34 \\
\hline
\end{tabular}

Keterangan: data diatas diperoleh dari pengukuran 3 arah yaitu secara vertical, horizontal dan diagonal

\section{B. Pembahasan}

Penelitian mengenai uji aktifitas antibakteri ekstrak etanol daun Bandotan (Ageratum conyzoides L.) terhadap Staphylococcus aureus ini mendapatkan hasil bahwa ekstrak etanol daun Bandotan mempunyai daya hambat terhadap pertumbuhan Staphylococcus aureus. Hal ini terbukti dengan terdapatnya diameter zona hambat disekitar paper disk yang mengandung ekstrak etanol daun Bandotan.

Berdasarkan hasil pengukuran diameter zona hambat, pada ekstrak etanol daun Bandotan konsentrasi $15 \%$ didapatkan nilai rata-rata $22,70 \mathrm{~mm}$, konsentrasi $25 \%$ didapatkan nilai rata-rata $25,13 \mathrm{~mm}$, konsentrasi $35 \%$ didapatkan nilai rata-rata 
26,94 mm, kontrol positif Sefadroxil didapatkan nilai rata-rata $33,34 \mathrm{~mm}$ dan kontrol negatif menggunakan DMSO (Dimetyhl sulfoxide) $10 \%$ ialah $0 \mathrm{~mm}$ atau tidak memiliki zona hambat.

Untuk mengetahui ada tidaknya pengaruh perbedaan konsentrasi ekstrak etanol daun Bandotan terhadap diameter daya hambat bakteri maka digunakan uji parametric one way ANOVA, tetapi sebelum dilakukan analisa data dengan uji one way ANOVA, maka data terlebih dahulu harus dilakukan uji normalitas dan homogenitas data. Dari hasil uji normalitas menggunakan uji Shapiro-Wilk (data dapat dilihat pada lampiran Tabel 5 ) didapatkan nilai signifikansi untuk masing-masing data $(\rho>0,05)$ yang artinya data terdistribusi normal, setelah itu dilakukan uji homogenitas menggunakan uji Levene (data dapat dilihat pada lampiran Tabel 6 ) didapatkan nilai signifikansi untuk daya hambat terhadap Staphylococcus aureus $\rho=0,939 \quad(\rho>0,05)$ dengan hasil tersebut maka dapat dilakukan pengujian lebih lanjut dengan menggunakan uji one way ANOVA.

Berdasarkan uji one way ANOVA (dapat dilihat pada lampiran Tabel 7) diketahui bahwa pada variabel terikat daya hambat Staphylococcus aureus nilai tidak signifikansinya $\rho=0,951 \quad(\rho<0,05)$ yang berarti terdapat perbedaan yang bermakna atau ada pengaruh perlakuan konsentrasi ekstrak etanol daun Bandotan terhadap daya hambat Staphylococcus aureus yang dihasilkan pada media agar.

Setelah mengetahui bahwa tidak ada perbedaan pada daya hambat bakteri Staphylococcus aureus yang dihasilkan pada media nutrient agar dengan 3 replikasi akibat pengaruh perlakuan dari ke-3 variasi konsentrasi ekstrak daun Bandotan mana saja yang berbeda dan tidak berbeda pengaruhnya terhadap daya hambat Staphylococcus aureus dilakukan uji LSD (data dapat dilihat pada lampiran Tabel 8) diperoleh bahwa tidak terdapat perbedaan yang bermakna tiap konsentrasi atau tidak ada pengaruh perlakuan konsentrasi ekstrak etanol daun Bandotan (Ageratum conyzoides L.) terhadap pertumbuhan Staphylococcus aureus dengan daya hambat terbesar yang dihasilkan pada konsentrasi $35 \%$ sebesar 26,94 mm. Sedangkan pada kontrol positif dan negatif terdapat perbedaan yang bermakna atau ada pengaruh perlakuan terhadap konsentrasi. Hasil ini menunjukkan bahwa semakin besar konsentrasi ekstrak etanol daun Bandotan maka zona hambat yang terbentuk juga akan semakin besar.

\section{PENUTUP}

\section{Kesimpulan}

Berdasarkan analisis statistik dan pembahasan terhadap hasil penelitian diperoleh kesimpulan bahwa tidak terdapat perbedaan yang bermakna tiap konsentrasi atau tidak ada pengaruh perlakuan konsentrasi ekstrak etanol daun Bandotan (Ageratum conyzoides L.) terhadap pertumbuhan Staphylococcus aureus dengan zona hambat terbesar yang dihasilkan pada konsentrasi 35\% sebesar 26,94 mm. Dari semua konsentrasi ekstrak etanol daun Bandotan (Ageratum conyzoides L.) mempunyai aktivitas antibakteri terhadap pertumbuhan Staphylococcus aureus

\section{Saran}

Disarankan untuk perlu dilakukan uji lanjutan seperti uji secara toksisitas dan uji klinis agar tanaman Bandotan khususnya daun dimanfaatkan secara maksimal. Serta dilakukan penelitian lebih lanjut dengan menggunakan jarak konsntrasi yang lebih luas. Agar diperoleh perbedaan daya hambat yang signifikan.

\section{DAFTAR PUSTAKA}

Alosia maria. 2017. Ekstraksi dan Real Kromatografi. Yogyakarta: CV Budi Utama

Andriani yuli. 2018. Budidaya Ikan Nila. Yogyakarta : CV Budi Utama

Depkes RI. 1986. Sediaan Gelanik. Jakarta

Dalimarta, setiawan dan Felix adria. 2013. Herbal tumpas penyakit. Jakarta; Penebar swadaya

Dwi rukmi. 2018. Rempah Untuk Pangan dan Kesehatan. Malang : UB Press

Dwidjoseputro. 2012. Dasar-dasar Mikrobiologi. Jakarta : Djambatan

Fetcsh Alexander, 2017. Staphylococus aureus. London. Academy Press

Harun nurhidayati. 2017. Uji Aktivitas Antibakteri Ekstrak Etanol Daun Bandaton (Ageratum conyzoides L) Terhadap Bakteri Staphylococcus aureus. Ciamis : Stikes Muhammadiyah.

Hariana. 2013. Tumbuhan Obat dan Khasiatnya. Jakarta : penebar swadaya

Hidayat. 2015. Kitab Tumbuhan Obat. Jakarta : penebar swadaya grup 
Irianto koes. 2013. Mikrobiologi Medis. Bandung : Alfabeta

Murwani sri. 2017. Penyakit Bakterial Pada Ternak Hewan Besar dan Unggas. Malang :UB Press

Pelezar. 2015. Dasar-dasar Mikrobioloogi. Jakarta : Universitas Indonesia

Ryan. 2015. Medical Microbiology An Introduction To Infectious Diseases. Connecticut Appleton \& Lange

Sutedjo. 2012. Mikrobiolgi Tanah. Jakarta : Rineka Cipta

Sutrisna. 2016. Herbal Medicine. Muhammadiyah University

Sugara. 2016. Uji Aktivitas Fraksi Etil Daun Tanaman Bandotan (Ageratum conyzoides L ). Mataram : Universitas Muhammadiyah

Ulung gagas. 2014. Sehat Alami dengan Herbal. Jakarta : Gramedia Pustaka Umum

Utami prapti. 2012. Antibiotik alami untuk mengatasi aneka penyakit. Jakarta : Agromedia Pustaka 